\title{
IL3 wt Allele
}

National Cancer Institute

\section{Source}

National Cancer Institute. IL3 wt Allele. NCI Thesaurus. Code C50935.

Human IL3 wild-type allele is located in the vicinity of 5q31.1 and is approximately $3 \mathrm{~kb}$ in length. This allele, which encodes interleukin-3 protein, plays a role in the induction of proliferation for many hematopoietic cell types. 